\title{
Emergence of resistance to tyrosine kinase inhibitors in non-small-cell lung cancer can be delayed by an upfront combination with the HSP90 inhibitor onalespib
}

\author{
Aurelie Courtin ${ }^{1}$, Tomoko Smyth ${ }^{1}$, Keisha Hearn ${ }^{1}$, Harpreet K Saini ${ }^{1}$, Neil T Thompson ${ }^{1}$, John F Lyons ${ }^{1}$ \\ and Nicola G Wallis ${ }^{*}, 1$ \\ ${ }^{1}$ Astex Pharmaceuticals, 436 Cambridge Science Park, Milton Road, Cambridge, CB4 0QA, UK
}

\begin{abstract}
Background: Tyrosine kinase inhibitors, such as crizotinib and erlotinib, are widely used to treat non-small-cell lung cancer, but after initial response, relapse is common because of the emergence of resistance through multiple mechanisms. Here, we investigated whether a frontline combination with an HSP9O inhibitor could delay the emergence of resistance to these inhibitors in preclinical lung cancer models.
\end{abstract}

Methods: The HSP90 inhibitor, onalespib, was combined with either crizotinib or erlotinib in ALK- or EGFR-activated xenograft models respectively (H2228, HCC827).

Results: In both models, after initial response to the monotherapy kinase inhibitors, tumour relapse was observed. In contrast, tumour growth remained inhibited when treated with an onalespib/kinase inhibitor combination. Analysis of H2228 tumours, which had relapsed on crizotinib monotherapy, identified a number of clinically relevant crizotinib resistance mechanisms, suggesting that HSP90 inhibitor treatment was capable of suppressing multiple mechanisms of resistance. Resistant cell lines, derived from these tumours, retained sensitivity to onalespib (proliferation and signalling pathways were inhibited), indicating that, despite their resistance to crizotinib, they were still sensitive to HSP9O inhibition.

Conclusions: Together, these preclinical data suggest that frontline combination with an HSP9O inhibitor may be a method for delaying the emergence of resistance to targeted therapies.

The molecular characterisation of cancers has highlighted the role of genetic alterations such as mutations or chromosomal rearrangements in the constitutive activation of tyrosine kinases, while the development of targeted therapies to these kinases has transformed the management of the disease. Two of the most wellrecognised genetic alterations are mutations in epidermal growth factor receptor (EGFR) and fusions of the echinoderm microtubule-associated protein-like-4 (EML4) to anaplastic lymphoma kinase (ALK) in non-small-cell lung cancers (NSCLC) (Paez et al, 2004; Soda et al, 2007). The NSCLC patients with such alterations benefit from treatment with FDA-approved tyrosine kinase inhibitors (TKIs) such as erlotinib or crizotinib (Pao et al, 2005; Kwak et al, 2010; Camidge et al, 2012), but invariably develop acquired resistance to therapy (Lovly and Shaw, 2014; Katayama et al, 2015). Investigation of relapse after treatment with TKIs has identified multiple resistance mechanisms, including gene amplification of primary oncogenes, secondary mutations in the drug targets and activation of circumventing signalling pathways. In mutant EGFR NSCLC the predominant mechanism of resistance is the EGFR T790M gatekeeper mutation with 
amplification of MET also reported (Pao et al, 2005; Bean et al, 2007; Kawakami et al, 2014). Diverse mechanisms of resistance to crizotinib have been identified in ALK-rearranged NSCLC. Secondary mutations of the drug target including mutation of the gatekeeper (L1196M) and other residues of the kinase domain (G1269A, L1152R, C1156Y and others) occur in about a third of patients, but EML4-ALK amplification and activation of alternative signalling pathways are also frequently observed (Choi et al, 2010; Doebele et al, 2012; Katayama et al, 2012).

The discovery of secondary mutations in these drug targets primed the development of next-generation TKIs, such as afatinib and AZD9291 (EGFR inhibitors) (Yang et al, 2012; Janne et al, 2015) or ceritinib and alectinib (ALK inhibitors) (Seto et al, 2013; Shaw et al, 2014). However, although these next-generation TKIs demonstrate some clinical activity in resistant disease, patients still eventually relapse because of intrinsic or newly acquired resistance mechanisms (Seto et al, 2013; Shaw et al, 2014; Ignatius Ou et al, 2014; Ou et al, 2015). The multiple mechanisms observed suggest that resistance is unlikely to be overcome by inhibiting a single drug target and that novel combination treatments will be needed to deal with this multifactorial process.

Heat shock protein 90 (HSP90) is a molecular chaperone that plays an essential role in maintaining cellular protein homeostasis and in intracellular trafficking of its protein clients (Pearl et al, 2008; Neckers and Workman, 2012). As EGFR, EML4-ALK and other key components of oncogenic signalling pathways are HSP90 clients (Shimamura et al, 2005; Normant et al, 2011), the use of HSP90 inhibitors has been investigated in NSCLC, both preclinically (Graham et al, 2012; Shimamura et al, 2012; Sang et al, 2013; Garon et al, 2013) and clinically (Sequist et al, 2010; Socinski et al, 2013; Johnson et al, 2015), and it has been suggested that this may be a method for overcoming diverse mechanisms of resistance (Sang et al, 2013; Lovly and Shaw, 2014). However, although HSP90 inhibitors have demonstrated some efficacy in both TKIsensitive and -resistant NSCLC preclinical models, responses to single-agent HSP90 inhibitor treatment in the clinic have been disappointing, highlighting the need to find new strategies to improve their therapeutic potential (Butler et al, 2015). In a previous study, we reported that an upfront combination of the potent second-generation HSP90 inhibitor, AT13387 (onalespib) (Woodhead et al, 2010), delayed the emergence of acquired resistance to vemurafenib in a BRAF ${ }^{\mathrm{V} 600 \mathrm{E}}$ melanoma model (Smyth et al, 2014). A ceritinib/MEK inhibitor combination has also been reported to improve response and forestall resistance in an ALK model (Hrustanovic et al, 2015). Here, we have expanded on the concept of using HSP90 inhibitor combinations upfront, demonstrating that they can be used more broadly to delay development of resistance to other kinase inhibitors in further disease models, specifically EGFR- and ALK-driven NSCLC.

\section{MATERIALS AND METHODS}

Materials. Onalespib (AT13387) was synthesised at Astex Pharmaceuticals (Cambridge, UK) as described by Woodhead et al (2010) and stored as a lyophilised powder. Crizotinib was purchased from Sequoia Research Products Ltd (Pangbourne, UK). Erlotinib and 17-AAG were purchased from LC Laboratories (Woburn, MA, USA). Ganetespib was purchased from Charnwood Molecular (Loughborough, UK). All other reagents were purchased from Sigma (Gillingham, UK) unless stated otherwise.

Cell culture and reagents. The human cell lines H2228 and HCC827 were purchased from the American Type Culture Collection (ATCC, Teddington, UK). Cells were grown in RPMI1640 medium supplemented with $10 \%$ FBS and maintained at $37^{\circ} \mathrm{C}$ in an atmosphere of $5 \% \mathrm{CO}_{2}$. All cell culture reagents were purchased from Invitrogen (Paisley, UK) unless stated otherwise. These cells lines were not passaged for more than 6 months after authentication by the cell bank (short tandem repeat PCR). The crizotinib-resistant H2228 cell lines (H2228-CR) were generated in-house and derived from EML4-ALK H2228 xenograft tumours that acquired resistance to crizotinib in vivo after continuous crizotinib monotherapy. Relapsing tumours were removed aseptically from mice and were mechanically dissociated and digested with collagenase IV $\left(200 \mathrm{U} \mathrm{ml}^{-1}\right)$. The digested mixtures were then filtered and centrifuged. Cell pellets were washed and resuspended in RPMI medium supplemented with 20\% FBS, penicillin/streptomycin and bovine pituitary extract $\left(30 \mu \mathrm{g} \mathrm{ml}^{-1}\right.$, BD Biosciences, Oxford, UK). Crizotinib $(1 \mu \mathrm{M})$ was added to cultures $24 \mathrm{~h}$ later. The resulting cell lines were named H2228-CR1, H2228-CR2, H2228-CR4, H2228-CR5, H2228-CR6 and H2228CR7. The crizotinib-sensitive control cell line (H2228-CS) was derived from a treatment-naive H2228 xenograft according to the same protocol without addition of crizotinib. After the first passage, all cell lines were cultured in RPMI-1640 medium supplemented with $10 \%$ FBS and $1 \mu \mathrm{M}$ crizotinib. Similar methods were used to generate HCC827 erlotinib-resistant cell lines from HCC827 xenograft tumours, with erlotinib $(0.3 \mu \mathrm{M})$ being added to cultures instead of crizotinib.

Exome sequencing. The $5 \times 10^{6} \mathrm{H} 2228$-CS and H2228-CR cells were harvested in triplicate, pelleted by centrifugation, snap frozen in liquid nitrogen and stored at $-80^{\circ} \mathrm{C}$. The DNA isolation and exome sequencing were performed by GATC Biotech (https:// www.gatc-biotech.com/en/index.html) according to their guidelines. Genomic DNA was extracted and exome sequencing was performed using Agilent SureSelect Human All Exon V5 kit (Stockport, UK). The sequencing library was constructed and analysed by the Illumina HiSeq 2500 (Little Chesterford, UK) using the 101-bp paired-end mode of the TruSeq SBS technology. Mean target coverage was $145.43 \pm 21.84$-fold. Bioinformatics analysis was carried out as described in Supplementary Data. Raw sequencing data have been deposited and are available at ArrayExpress under accession code E-MTAB-4851.

Determination of proliferation by live cell imaging. To measure proliferation in real time, $5 \times 10^{3}$ cells were seeded in $200 \mu \mathrm{l}$ of complete culture medium per well into flat-bottomed 96-well plates and incubated overnight at $37^{\circ} \mathrm{C}$ in a humidified atmosphere of $5 \% \mathrm{CO}_{2}$ in air. Cells were incubated with compound in $0.1 \%(\mathrm{v} / \mathrm{v})$ dimethyl sulphoxide (DMSO) for 7 days and images captured using an IncuCyte ZOOM live cell microscope (Essen BioScience, Ann Arbor, MI, USA). Live images were taken every $3 \mathrm{~h}$ over 7 days using a $10 \times$ objective and IncuCyte software was used to calculate mean percent confluency from four nonoverlapping phase-contrast images of each well. Relative proliferation was calculated from the area under the curve (AUC). The $\mathrm{IC}_{50}$ values were generated using a sigmoidal dose response equation (Prism GraphPad software, La Jolla, CA, USA).

Protein analysis. For western blotting, cells were seeded into 6 -well plates at $5 \times 10^{5}$ cells per well in $2 \mathrm{ml}$ of complete medium, incubated overnight at $37^{\circ} \mathrm{C}$ and then treated with HSP90 inhibitor or crizotinib for $24 \mathrm{~h}$. Samples were harvested post treatment and lysed in $150 \mu \mathrm{l}$ of ice-cold Triton lysis buffer. After a freeze-thaw cycle, lysates were cleared by centrifugation at 14000 r.p.m. for $5 \mathrm{~min}$ at $4{ }^{\circ} \mathrm{C}$. Protein concentrations were determined by BCA protein assay (Pierce, Paisley, UK) and normalised. Samples were resolved by SDS-PAGE, blotted onto nitrocellulose filters, blocked with Odyssey Blocking Buffer (LICOR Biosciences, Lincoln, NE, USA) and incubated overnight with the specific antibodies to: ALK, phospho-S6 ${ }^{(\text {Ser240/244) }}$, S6, phospho$\mathrm{AKT}^{(\mathrm{Ser} 473)}$, AKT, phospho-ERK1/2 ${ }^{\text {(Thr202/Tyr204) }}$, ERK1/2, MET, phospho-EGFR ${ }^{(\text {Tyr1068) }}$, EGFR, STAT3, phospho-STAT3 ${ }^{\text {(Tyr705) }}$ (Cell $^{\text {'ST }}$ 
Signaling Technology, Hitchin, UK), HSP70 (Stressgen, Ann Arbor, MI, USA) and actin (Abcam, Cambridge, UK). After washing, blots were incubated with infrared dye-labelled anti-rabbit and anti-mouse antibodies (LI-COR Biosciences). Blots were scanned to detect infrared fluorescence on the Odyssey infrared imaging system (LI-COR Biosciences).

To measure levels of phospho-ALK, $1 \times 10^{5}$ cells were seeded in $200 \mu \mathrm{l}$ of complete culture medium per well into flat-bottomed 96-well plates and incubated overnight at $37^{\circ} \mathrm{C}$. Samples were then harvested, lysed in $50 \mu \mathrm{l}$ of ice-cold lysis buffer and analysed using the PathScan Phospho-ALK (Tyr1604) Chemiluminescent Sandwich ELISA Kit (Cell Signalling Technology, Danvers, MA, USA).

Xenograft studies. The H2228, H2228-CR6 and HCC827 xenografts were prepared by subcutaneously injecting $5 \times 10^{6}$ cells suspended in serum-free medium mixed $1: 1$ with Matrigel (BD Biosciences) into the right flank of each male BALB/c SCID mouse. Tumours were measured using caliper and tumour volumes calculated by applying the formula for an ellipsoid. When the tumours reached an average of $80-120 \mathrm{~mm}^{3}$, mice were randomised into groups of $8-12$. Onalespib was dissolved in aqueous solution of $17.5 \%(\mathrm{w} / \mathrm{v})$ (2-hydroxypropyl)- $\beta$-cyclodextrin and intraperitoneally administered weekly at $55 \mathrm{mg} \mathrm{kg}^{-1}$. Crizotinib was suspended in water and given daily at $50 \mathrm{mg} \mathrm{kg}^{-1}$ by oral gavage. Erlotinib, suspended in $0.3 \%(\mathrm{w} / \mathrm{v})$ carboxymethylcellulose and $0.1 \%(\mathrm{v} / \mathrm{v})$ Tween-80, was administered daily at $12.5 \mathrm{mg} \mathrm{kg}^{-1}$ by oral gavage. All drugs were given at a dose volume of $10 \mathrm{ml} \mathrm{kg}^{-1}$. Treated $v s$ control $(\mathrm{T} / \mathrm{C})$ ratio was calculated as $100 \times$ mean treated volume divided by mean control volume. Tolerability was estimated by monitoring body weight and general health over the course of the study. To expand the crizotinibresistant and -sensitive tumours, mice bearing H2228 xenografts were killed and tumours removed immediately under aseptic condition. The tumours were washed and cut into pieces $\sim 3 \mathrm{~mm}^{3}$ in serum-free RPMI-1640 medium and subcutaneously implanted into naive mice under general anaesthesia. Subsequently, mice were treated with crizotinib daily. The care and the treatment of animals were in accordance with the United Kingdom Coordinating Committee for Cancer Research guidelines and with the United Kingdom Animals (Scientific Procedures) Act 1986 (Hollands, 1986; Workman et al, 2010). All scientific procedures were performed under the United Kingdom Home Office Project License approved by the University of Cambridge Animal Welfare and Ethical Review Committee.

Statistical analysis. Statistical analyses were performed using GraphPad Prism version 6.05. The effects of treatments were compared using one-way ANOVA or $t$-test. Differences were deemed statistically significant when $P<0.05$.

\section{RESULTS}

Onalespib delays the emergence of resistance to crizotinib and erlotinib in in vivo models of NSCLC. We have previously established that an upfront combined treatment of onalespib and vemurafenib in BRAF ${ }^{\mathrm{V} 600 \mathrm{E}}$ mutant melanoma delays the emergence of resistance to vemurafenib (Smyth et al, 2014). In order to expand these findings to other targeted therapies of clinical relevance, we extended our studies to NSCLC using two xenograft models, an erlotinib-sensitive EGFR ${ }^{\text {del746_750 }}$ model (HCC827) and a crizotinib-sensitive EML4-ALK translocated model (H2228). In these two models we compared the efficacy of the targeted therapy as a single agent or in combination with onalespib over an extended timescale in order to evaluate relative times of relapse and emergence of resistance while on treatment, in line with clinical timescales. In the HCC 827 erlotinib-naive model, $12.5 \mathrm{mg} \mathrm{kg}^{-1}$ erlotinib was given as monotherapy or in combination with $55 \mathrm{mg} \mathrm{kg}^{-1}$ onalespib to mice bearing xenograft tumours. As expected, erlotinib alone caused regression of tumours, whereas onalespib monotherapy caused moderate, but significant, tumour growth inhibition. Used together, onalespib significantly enhanced the antitumour activity of erlotinib (5.1\% vs $16.4 \% \mathrm{~T} / \mathrm{C}$ respectively, $P<0.0001 v s$ erlotinib monotherapy) over an initial period of 50 days, after which all tumours treated with erlotinib monotherapy and the combination achieved complete regression $(<3 \mathrm{~mm}$ diameter) with a median time of 58 and 79 days, respectively (Figure 1A). Both erlotinib monotherapy and combination treatments were continued over a total period of 53 weeks. During this time, 3 out of 12 tumours treated with erlotinib relapsed, reaching $50 \%$ of their original volume by weeks 21, 26 and 46, whereas 5 other tumours showed sign of regrowth by the end of the study period (Figure 1B-D). At the end of the treatment period, the erlotinib-treated tumours from the 7 remaining mice ranged in volume from 0 to $89 \mathrm{~mm}^{3}$, whereas, in contrast, the 9 tumours from the combination-treated mice were still not palpable (Figure $1 \mathrm{~B}$ and $\mathrm{D}$ ). The combination-treated mice were monitored for several weeks after the end of treatment and all tumours remained undetectable for a further 6 weeks of observation, after which signs of tumour regrowth were observed in three out of the eight remaining mice, demonstrating the extended benefit of the combination treatment (Figure 1E).

In a similar experiment, the activity of crizotinib as a monotherapy or in combination with onalespib was compared in H2228 (EML4-ALK) crizotinib-naive tumours (Figure 2). Over an initial period of 35 days, onalespib monotherapy significantly inhibited the growth of $\mathrm{H} 2228$ tumours compared with the control (46\% T/C, $P<0.0001$ ), whereas crizotinib monotherapy induced significant tumour regression, as expected. The combination of onalespib and crizotinib showed an improvement on tumour regression over crizotinib monotherapy ( $3 \%$ vs $11 \% \mathrm{~T} / \mathrm{C}, 87 \%$ vs $63 \%$ regression on day 35); however, the difference was not statistically significant (Figure 2A). The crizotinib monotherapy and combination treatments were extended for a period of 3 months during which three out of the eight crizotinib-treated tumours relapsed, whereas no sign of regrowth was observed in the combination-treated tumours (Figure $2 \mathrm{~B}$ and $\mathrm{C}$ ). The combinations of onalespib with either erlotinib or crizotinib were well tolerated with no significant increase in toxicity observed (Supplementary Figure S1).

Taken together, these data demonstrate that onalespib can delay the emergence of resistance to targeted therapies, including erlotinib and crizotinib in EGFR ${ }^{\text {del746-750 }}$ and EML4-ALK NSCLC tumour models, respectively.

Characterisation of crizotinib resistance in $\mathrm{H} 2228$ tumours. In order to determine which resistance mechanisms HSP90 inhibitor treatment might be preventing, we next investigated crizotinib resistance in the H2228 xenograft model. Crizotinib-resistant tumours were generated by continuous treatment of mice bearing H2228 xenograft tumours with crizotinib (Supplementary Figure S2). The relapsed tumours were excised and cultured ex vivo (tumour \#1) or implanted for a second passage in crizotinibtreated mice before being cultured ex vivo (tumours \#2, \#4, \#5, \#6 and $\# 7$ ). The resistance to crizotinib of the resulting $\mathrm{H} 2228$ cell lines (H2228-CR1, H2228-CR2, H2228-CR4, H2228-CR5, H2228CR6 and H2228-CR7, respectively) was established by measuring proliferation rates by time-lapse microscopy in the presence of crizotinib (Supplementary Figure S3). For comparison a cell population was generated from a treatment-naive tumour $(\mathrm{H} 2228$ CS). Exome sequencing was used to characterise the H2228 cell lines. Details, including sequencing statistics (raw and mapped reads) for each sample, are provided in Supplementary Data and Supplementary Tables S1 and S2. A spectrum of genetic alterations 
A



C

\begin{tabular}{cc}
\hline $\begin{array}{c}\text { Erlotinib- } \\
\text { treated tumour }\end{array}$ & $\begin{array}{c}\text { Time to 50\% original } \\
\text { tumour volume } \\
\text { (weeks) }\end{array}$ \\
\hline 1 & 21 \\
2 & 26 \\
3 & 46 \\
\hline
\end{tabular}

D

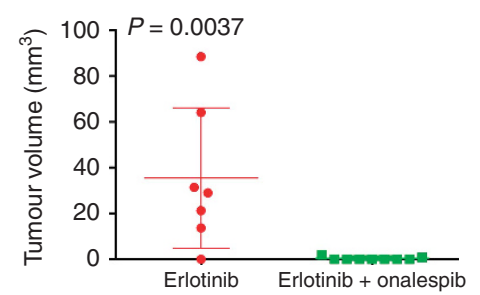

B

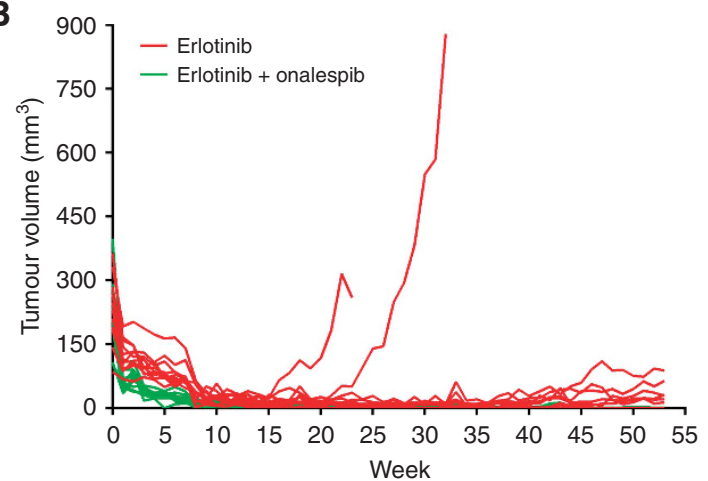

Figure 1. Onalespib treatment delays the emergence of resistance to erlotinib in vivo. (A) Mice bearing HCC827 xenograft tumours received onalespib $55 \mathrm{mg} \mathrm{kg}^{-1}$ or its vehicle, cyclodextrin, i.p. once a week. Erlotinib was administered at $12.5 \mathrm{mg} \mathrm{kg}^{-1}$ orally and daily. Tumour volumes are represented as the mean \pm s.e.m. of $n=8$ (onalespib and cyclodextrin) or $n=12$ (erlotinib and erlotinib plus onalespib). (B) Erlotinib monotherapy and erlotinib/onalespib combination treatments were continued to allow resistance to develop. Volumes of individual tumours over the full study period of 53 weeks are presented. (C) Time at which HCC827 tumours with acquired resistance to erlotinib reached $50 \%$ of their original volume. (D) Individual tumour volumes of erlotinib- or combination-treated HCC827 tumours on the last day of treatment on week 53. (E) Comparison of individual tumour volumes of combination-treated tumours at the end of the treatment period and at 10 weeks post treatment.
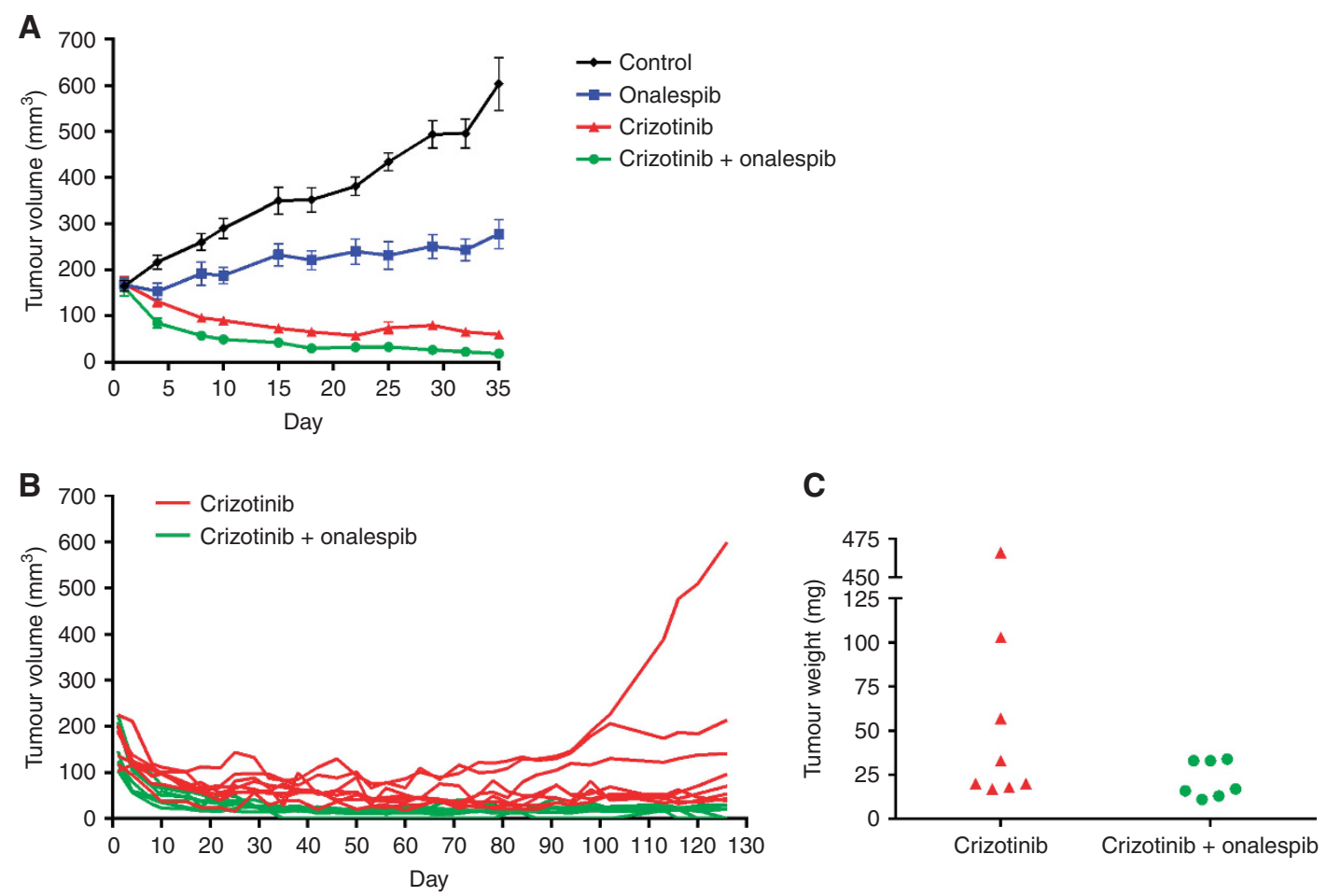

Figure 2. Onalespib treatment delays the emergence of resistance to crizotinib in vivo. (A) Mice bearing $\mathrm{H} 2228$ xenograft tumours received onalespib $55 \mathrm{mg} \mathrm{kg}^{-1}$ or its vehicle, cyclodextrin, i.p. once a week. Crizotinib was administered at $50 \mathrm{mg} \mathrm{kg}^{-1}$ orally and daily. Tumour volumes are represented as the mean \pm s.e.m. of $n=8$ (onalespib and cyclodextrin) or $n=12$ (crizotinib and crizotinib plus onalespib). (B) Volumes of individual tumours in the crizotinib monotherapy and crizotinib/onalespib combination groups were monitored over a total period of 125 days to allow resistance to develop. (C) Individual tumour weights of crizotinib- or combination-treated H2228 tumours on the last day of treatment on day 125. 
A

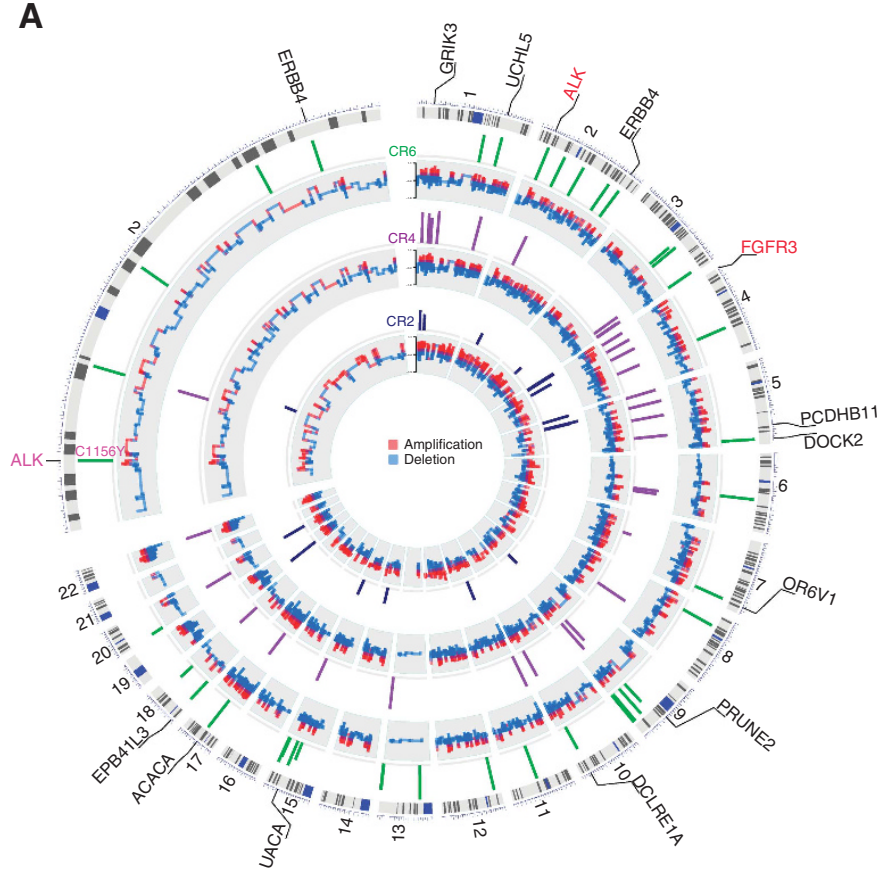

B
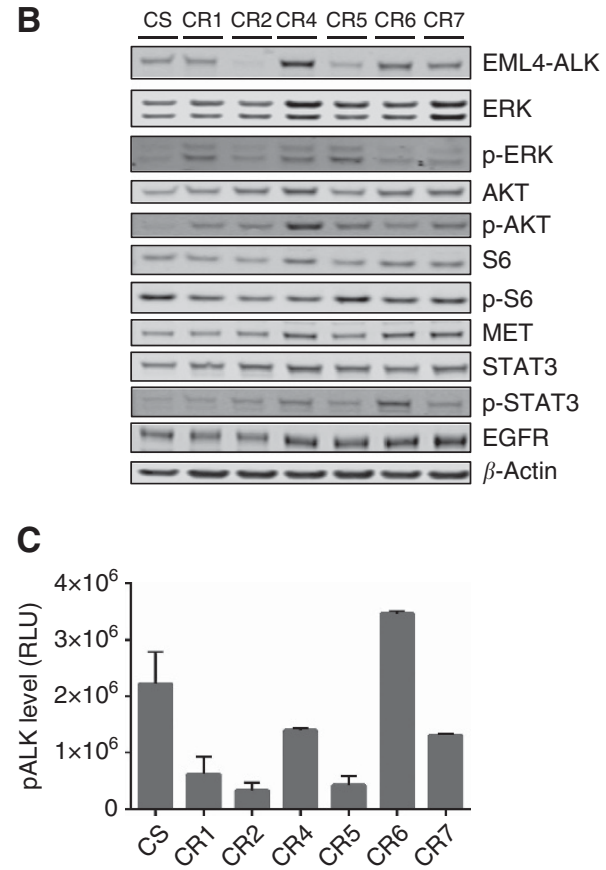

Figure 3. Characterisation of ex vivo crizotinib-resistant cell lines. (A) Circos plot displaying nonsynonymous somatic mutations and copy number variations in H2228-CR2, -CR4 and -CR6 samples (compared with H2228-CS) that were analysed after exome sequencing. Mutations are displayed as coloured radial lines and those predicted as functional are labelled. The inner ring displays copy number data for each sample. Zoomed chromosome 2 is displayed in the top left section. (B) Analysis of ALK signalling pathway by western blot in ex vivo H2228 cell lines (CR = crizotinib resistant; CS = crizotinib sensitive). (C) Measure of the basal level of pALK in H2228-CS and -CR cell lines by ELISA.

was detected (Figure 3A and Supplementary Figure S4). Deletion of EML4-ALK was predicted in the H2228-CR2 cell line, whereas amplification of ALK was observed in the H2228-CR4 and -CR6 lines. The somatic mutation $\mathrm{C} 1156 \mathrm{Y}$ was also identified in the EML4-ALK gene of H2228-CR6 cells (Figure 3A). The ALK deletion, amplification and mutation have all been previously associated with crizotinib resistance in the clinic (Choi et al, 2010; Doebele et al, 2012; Katayama et al, 2012). No EGFR, KRAS or MET mutations were found in any of the resistant cell lines, but an additional amplification of FGFR3 was identified in H2228-CR6 cells. Several predicted driver mutations were also detected in the different H2228-CR cell lines that could represent potential candidate genes for crizotinib resistance (Supplementary Table S3).

We further characterised the H2228-CR cell lines in more biochemical detail by analysing levels of proteins involved in the ALK signalling pathway by western blot (Figure 3B) and phosphoALK levels by ELISA (Figure 3C). Changes in protein levels were observed in the resistant compared with the sensitive cell lines, suggesting resistance was associated with changes in signalling. There appeared to be an increased level of phospho-ERK, accompanied by a decrease in phospho-ALK levels in H2228CR1 compared with H2228-CS, but no other clear differences were observed between the two cell lines. The EML4-ALK protein was not detected in the H2228-CR2 cell line, in line with the genetic data, and the decrease in phospho-ALK levels reflected this. The H2228-CR4 and H2228-CR6 cell lines exhibited increased levels of total EML4-ALK protein in agreement with the exome sequencing data. In H2228-CR4, the increased level of EML4-ALK was not accompanied by an increase in phospho-ALK levels but a concomitant increase in the levels of proteins including ERK, AKT and their phospho-forms as well as MET and EGFR was observed. In H2228-CR6 phospho-ALK AKT, MET and phospho-STAT3 levels appeared to be increased. This cell line was less sensitive to inhibition of phospho-ALK by crizotinib compared with H2228CS (Supplementary Figure S5A), consistent with the presence of the C1156Y mutation that reduces the affinity of crizotinib for this mutant ALK protein. The H2228-CR5 exhibited a decrease in total and phospho-ALK levels, but increases in phospho-ERK, phosphoAKT and EGFR levels were observed. Finally, H2228-CR7 cells appeared to have higher levels of ERK, phospho-AKT, MET and EGFR than the H2228-CS cells (Figure 3B). Taken together, these results suggest that the $\mathrm{H} 2228$ tumours acquired resistance to crizotinib through different mechanisms such as the loss of EML4ALK (CR2), the overexpression of EML4-ALK (CR4 and CR6), ALK mutation (CR6) and/or activation of alternative pathways (CR1, CR5 and CR7).

A similar attempt to generate ex vivo cultures from erlotinibresistant HCC827 xenograft tumours was not successful; no clinically relevant modifications were identified by the exome sequencing analysis in the limited material obtained.

Onalespib maintains activity in models with acquired resistance to crizotinib. The H2228-CR2 (ALK $\left.{ }^{\mathrm{del}}\right), \mathrm{H} 2228-\mathrm{CR} 4$ (ALK $^{\mathrm{amp}}$ ) and H2228-CR6 (ALK ${ }^{\mathrm{amp}}, \mathrm{ALK}^{\mathrm{C} 1156 \mathrm{Y}}$ ) cell lines harbour changes in ALK that have been described in patients with NSCLC who relapsed under crizotinib treatment (Choi et al, 2010; Katayama et al, 2012; Doebele et al, 2012). We therefore evaluated the activity of onalespib and the HSP90 inhibitors ganetespib and 17-AAG in these clinically relevant cell lines (Figure 4 and Supplementary Figures S3 and S5). For this purpose, we treated the cells with a dose range of HSP90 inhibitor or crizotinib and proliferation was followed by time-lapse microscopy. Measurement of cell confluence showed that proliferation is inhibited from $0.1 \mu \mathrm{M}$ onalespib in the three cell lines, whereas crizotinib had no effect at concentrations below $3 \mu \mathrm{M}$ (Figure $4 \mathrm{~A}$ and Supplementary Figure S3). In some cases, crizotinib-treated cell growth was even increased compared with vehicle-treated cell growth, suggesting a stimulatory effect of crizotinib at certain concentrations in crizotinib-resistant cell lines. The effects of onalespib and crizotinib on cell signalling were then compared. As expected, HSP90 
A



B
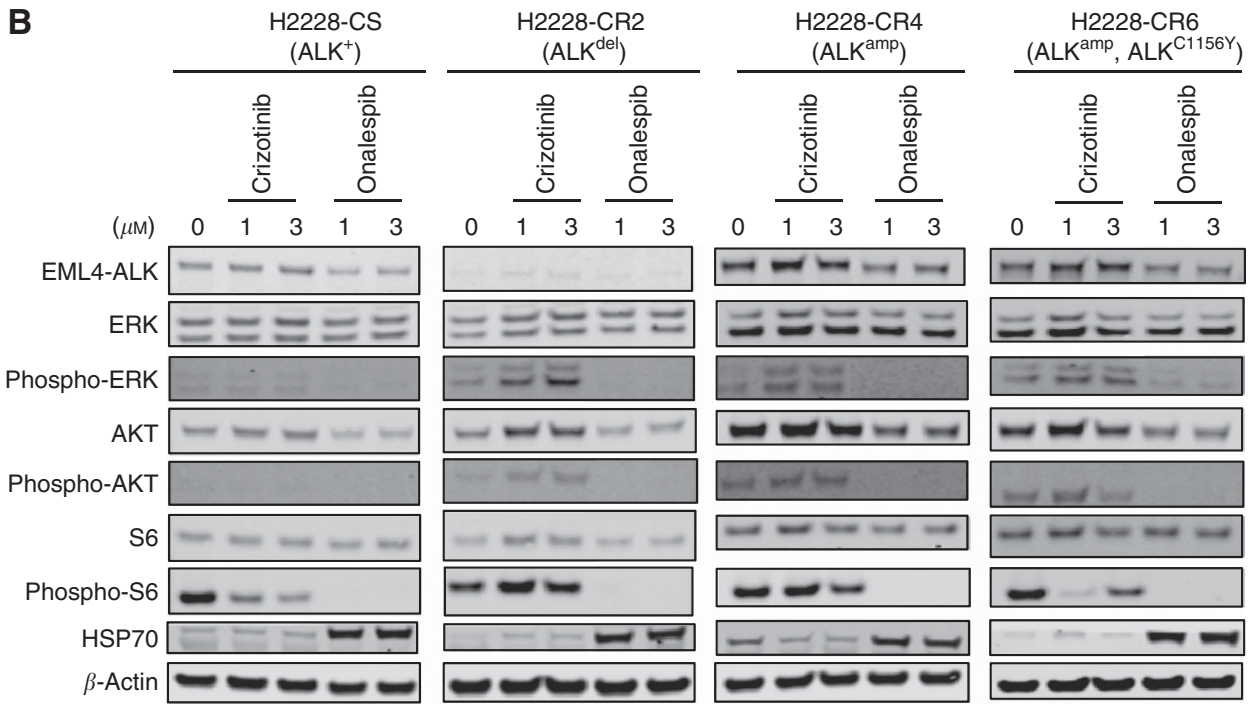

Figure 4. Crizotinib-resistant cell lines remain sensitive to onalespib in vitro. (A) The ex vivo crizotinib-sensitive (H2228-CS) and crizotinib-resistant (H2228-CR2, -CR4, -CR6) cell lines were treated with crizotinib or onalespib at concentrations ranging from 0 to $10 \mu \mathrm{M}$. Proliferation was measured in real time for 7 days using cell live microscopy and expressed as the mean percent confluency. (B) The H2228-CR and H2228-CS cells were treated with crizotinib or onalespib at the indicated concentrations for $24 \mathrm{~h}$. The effect on levels of proteins associated with the ALK signalling pathway was measured by western blot.

inhibitor treatment induced HSP70 expression, confirming HSP90 inhibition, in the three cell lines (Figure 4B and Supplementary Figure 5B). A concomitant depletion in the level of phospho-ERK, phospho-AKT and phospho-S6 demonstrated that ALK signalling was inhibited by HSP90 inhibitor treatment. In contrast, the levels of these phosphorylated proteins were not decreased by treatment of the resistant cells with crizotinib (apart from a slight decrease in pS6 levels in H2228-CR6) and in some cases appeared increased (Figure 4B). These data demonstrate that NSCLC cells with acquired resistance to crizotinib remain sensitive to HSP90 inhibition in vitro.

Onalespib is active in a crizotinib-resistant (ALK C1156Y) xenograft model. To further investigate the activity of onalespib in crizotinib-resistant models in vivo, we generated crizotinibresistant xenograft tumours, harbouring the ALK C1156Y kinase domain mutation, by implanting $\mathrm{H} 2228-\mathrm{CR} 6$ cells in BALB/c SCID mice. Animals were then treated with $50 \mathrm{mg} \mathrm{kg}^{-1}$ crizotinib as a monotherapy or in combination with $55 \mathrm{mg} \mathrm{kg}^{-1}$ onalespib. As expected, crizotinib alone did not inhibit tumour growth. However, the combination of crizotinib and onalespib induced a

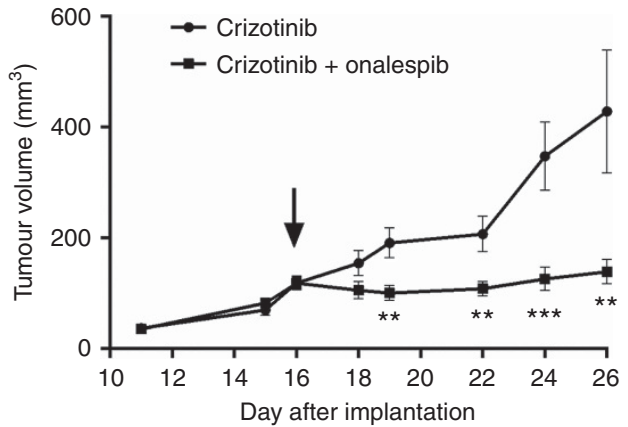

Figure 5. Onalespib is effective in crizotinib-resistant tumours. The H2228-CR6 tumours were grown subcutaneously in mice continuously treated with crizotinib (50 $\mathrm{mg} \mathrm{kg}^{-1}$, p.o.) to maintain resistance. Mice were randomised 16 days after tumour implantation (arrow) and treatment with either onalespib ( $55 \mathrm{mg} \mathrm{kg}^{-1}$ weekly, i.p.) or with vehicle (cyclodextrin, i.p.) was added. Tumour volumes are presented as the mean \pm s.e.m. of $n=8$ (crizotinib) or $n=12$ (combination treatment); ${ }^{\star \star} P<0.01,{ }^{\star \star \star} P<0.001$. 
significant growth inhibition from day 3 of treatment (Figure 5). On day 26 of the study, the combination-treated tumours were $32.5 \%$ the size of those treated with crizotinib monotherapy $(P<0.01)$ and 3 out of 12 tumours reached the criteria for partial regression ( $>50 \%$ reduction) during the study period. These data suggest that onalespib can inhibit the growth of crizotinib-resistant tumours bearing the ALK C1156Y mutation. However, in contrast to the activity in the crizotinib-naive H2228 tumours (Figure 2A), the addition of onalespib here induced tumour stasis rather than tumour regression. This further suggests that using an upfront combination of onalespib with a TKI to delay acquired resistance could be more effective than treatment after resistance has developed.

\section{DISCUSSION}

The HSP90 inhibition has been investigated as a means of overcoming drug resistance in cancer because of its ability to affect multiple signalling pathways simultaneously (Shimamura et al, 2008; Paraiso et al, 2012; Smyth et al, 2012; Sang et al, 2013). However, despite promising preclinical data, response rates in clinical trials have been disappointing. Previously, we demonstrated preclinically that an upfront combination of the HSP90 inhibitor, onalespib, with the BRAF inhibitor, vemurafenib, delayed the emergence of resistance in a melanoma model (Smyth et al, 2014). Here we have expanded this concept, demonstrating that it is broadly applicable to other indications (ALK- and EGFR-driven NSCLC) and other kinase inhibitors (crizotinib, erlotinib). We showed in two different NSCLC models that an upfront combination of an HSP90 inhibitor and a kinase inhibitor can maintain tumour growth inhibition over timescales where relapse is seen to the monotherapy; timescales consistent with those where relapse is observed in the clinic.

The mechanisms of resistance that arise in these in vivo NSCLC models, on treatment with crizotinib, were investigated and clinically relevant mechanisms of resistance were identified (amplification or mutation (C1156Y) of EML4-ALK), although exome sequencing may not identify all resistance mechanisms. The H2228 xenograft model treated with crizotinib has been previously used to detect multiple clinically relevant secondary ALK mutations, including C1156Y (Friboulet et al, 2014). Moreover, in vitro and in vivo EML4-ALK- and EGFR-driven NSCLC models have been used to identify mechanisms of resistance involving oncogene driver mutations, EMT or activation of bypassing signalling pathways (Tanizaki et al, 2012; Katayama et al, 2012; Kim et al, 2013; Yamaguchi et al, 2014; Wilson et al, 2015). Many of these have also been observed in the clinical situation, suggesting that these preclinical models are useful tools for studying resistance development. The fact that we saw no relapse on TKI treatment in combination with the HSP90 inhibition also suggests that HSP0 inhibitors may be able to suppress multiple clinically relevant resistance mechanisms in these models, and hence their use may be widely applicable to address the emergence of resistance to targeted agents.

In order to overcome acquired drug resistance in patients, second-generation ALK and EGFR inhibitors have been developed. Second-generation ALK inhibitors, such as ceritinib and alectinib, are active against many ALK resistance mutations and have good clinical activity in crizotinib-resistant patients (Katayama et al, 2015). Nevertheless, ultimately resistance rearises to these agents through further ALK mutations or bypass pathways (Katayama et al, 2014, 2015). Similarly, although progression-free survival can be improved with EGFR inhibitors such as afatinib or AZD9291, resistance is inevitable (Yu et al, 2014; Thress et al, 2015). Secondand third-line inhibitors of the same target are highly likely to suffer from similar resistance mechanisms, and therefore different approaches are being investigated. It has been suggested that HSP90 inhibition is a potential approach for tackling resistance in the post-TKI treatment setting (Sang et al, 2013; Katayama et al, 2015), but despite some clinical activity in crizotinib-naive patients (Sequist et al, 2010; Socinski et al, 2013), lower response rates have been reported in patients with prior TKI treatment (Socinski et al, 2013; Johnson et al, 2015), suggesting that this may not be the optimum use of an HSP90 inhibitor. Here, we observed that in an in vivo model with acquired resistance to crizotinib, inhibition of tumour growth could be achieved by combination with an HSP90 inhibitor. However, effects on tumour growth were not as pronounced as treatment before the emergence of resistance. Our data suggest that combining an HSP90 inhibitor upfront with a TKI is a more effective approach to delay the emergence of resistance and potentially to prolong PFS.

It has been suggested previously that the simultaneous treatment of tumours with two drugs is more effective than sequential therapy (Bozic et al, 2013) and, indeed, although the combination of onalespib and crizotinib still inhibited tumour growth of the tumours with acquired crizotinib resistance, the inhibition was not as complete or sustained as observed in the sensitive tumours. Tumours initially respond to kinase inhibitors such as erlotinib and crizotinib, as we have observed here, but responses are short lived as tumours evolve to become resistant. This resistance can either be because of a small number of resistant cells in the original tumour that expand as the sensitive cells are treated or the emergence of de novo resistance mutations during treatment (Bozic et al, 2013). Treating with two agents simultaneously, which target different pathways, can overcome the first of these (Hrustanovic et al, 2015) using an HSP90 inhibitor as one of these agents gives an added advantage in such a combination, as it targets multiple pathways. However, HSP90 inhibition may have a more fundamental effect on the development of resistance because of its proposed role in the evolutionary process, stabilising mutated proteins and therefore modulating genetic variation as described by the capacitor hypothesis (Rohner et al, 2013). Inhibiting HSP90 could prevent this evolution of new phenotypes and hence limit the emergence of de novo mutations leading to drug resistance (Whitesell et al, 2014). An upfront combination with an HSP90 inhibitor could therefore address both these processes for development of resistance in our models, whereas the capacitor role will not be affected by inhibition of HSP90 after resistance has arisen. Multiple factors will affect which of these processes predominate in the clinic compared with preclinical models: tumour heterogeneity, types of pretreatment and stage of progression. Selecting the patient population in which this type of upfront combination will be most effective clinically may still be a challenge.

Overall, we have now shown in three preclinical models with different transforming oncogenes that combining HSP90 upfront with a suitable kinase inhibitor can delay the emergence of resistance (Smyth et al, 2014). A phase 2 trial (ClinicalTrials.gov Identifier: NCT01712217) is currently testing the combination of onalespib and crizotinib. Our preclinical data suggest that upfront combinations of HSP90 inhibitors and targeted agents may be applicable more generally for limiting the emergence of resistance and hence testing in further patient populations could also be warranted.

\section{ACKNOWLEDGEMENTS}

We are grateful to Jon Lewis for help with in vivo work, Mike Reader for help sourcing crizotinib and erlotinib for use in these experiments and Harold Keer and Mohammad Azab for useful discussion. 


\section{CONFLICT OF INTEREST}

AC, TS, KH, HKS, NTT, JFL and NGW are employees of Astex Pharmaceuticals.

\section{REFERENCES}

Bean J, Brennan C, Shih JY, Riely G, Viale A, Wang L, Chitale D, Motoi N, Szoke J, Broderick S, Balak M, Chang WC, Yu CJ, Gazdar A, Pass H, Rusch V, Gerald W, Huang SF, Yang PC, Miller V, Ladanyi M, Yang CH, Pao W (2007) MET amplification occurs with or without T790M mutations in EGFR mutant lung tumors with acquired resistance to gefitinib or erlotinib. Proc Natl Acad Sci USA 104: 20932-20937.

Bozic I, Reiter JG, Allen B, Antal T, Chatterjee K, Shah P, Moon YS, Yaqubie A, Kelly N, Le DT, Lipson EJ, Chapman PB, Diaz Jr LA, Vogelstein B, Nowak MA (2013) Evolutionary dynamics of cancer in response to targeted combination therapy. Elife 2: e00747.

Butler LM, Ferraldeschi R, Armstrong HK, Centenera MM, Workman P (2015) Maximizing the therapeutic potential of HSP90 inhibitors. Mol Cancer Res 13: 1445-1451.

Camidge DR, Bang YJ, Kwak EL, Iafrate AJ, Varella-Garcia M, Fox SB, Riely GJ, Solomon B, Ou SH, Kim DW, Salgia R, Fidias P, Engelman JA, Gandhi L, Janne PA, Costa DB, Shapiro GI, Lorusso P, Ruffner K, Stephenson P, Tang Y, Wilner K, Clark JW, Shaw AT (2012) Activity and safety of crizotinib in patients with ALK-positive non-small-cell lung cancer: updated results from a phase 1 study. Lancet Oncol 13: 1011-1019.

Choi YL, Soda M, Yamashita Y, Ueno T, Takashima J, Nakajima T, Yatabe Y, Takeuchi K, Hamada T, Haruta H, Ishikawa Y, Kimura H, Mitsudomi T, Tanio Y, Mano H. ALK Lung Cancer Study Group (2010) EML4-ALK mutations in lung cancer that confer resistance to ALK inhibitors. $N$ Engl J Med 363: 1734-1739.

Doebele RC, Pilling AB, Aisner DL, Kutateladze TG, Le AT, Weickhardt AJ, Kondo KL, Linderman DJ, Heasley LE, Franklin WA, Varella-Garcia M, Camidge DR (2012) Mechanisms of resistance to crizotinib in patients with ALK gene rearranged non-small cell lung cancer. Clin Cancer Res 18: 1472-1482.

Friboulet L, Li N, Katayama R, Lee CC, Gainor JF, Crystal AS, Michellys PY, Awad MM, Yanagitani N, Kim S, Pferdekamper AC, Li J, Kasibhatla S, Sun F, Sun X, Hua S, McNamara P, Mahmood S, Lockerman EL, Fujita N, Nishio M, Harris JL, Shaw AT, Engelman JA (2014) The ALK inhibitor ceritinib overcomes crizotinib resistance in non-small cell lung cancer. Cancer Discov 4: 662-673.

Garon EB, Finn RS, Hamidi H, Dering J, Pitts S, Kamranpour N, Desai AJ, Hosmer W, Ide S, Avsar E, Jensen MR, Quadt C, Liu M, Dubinett SM, Slamon DJ (2013) The HSP90 inhibitor NVP-AUY922 potently inhibits non-small cell lung cancer growth. Mol Cancer Ther 12: 890-900.

Graham B, Curry J, Smyth T, Fazal L, Feltell R, Harada I, Coyle J, Williams B, Reule M, Angove H, Cross DM, Lyons J, Wallis NG, Thompson NT (2012) The heat shock protein 90 inhibitor, AT13387, displays a long duration of action in vitro and in vivo in non-small cell lung cancer. Cancer Sci 103: 522-527.

Hollands C (1986) The Animals (scientific procedures) Act 1986. Lancet 2: $32-33$.

Hrustanovic G, Olivas V, Pazarentzos E, Tulpule A, Asthana S, Blakely CM, Okimoto RA, Lin L, Neel DS, Sabnis A, Flanagan J, Chan E, Varella-Garcia M, Aisner DL, Vaishnavi A, Ou SH, Collisson EA, Ichihara E, Mack PC, Lovly CM, Karachaliou N, Rosell R, Riess JW, Doebele RC, Bivona TG (2015) RAS-MAPK dependence underlies a rational polytherapy strategy in EML4-ALK-positive lung cancer. Nat Med 21: 1038-1047.

Ignatius Ou SH, Azada M, Hsiang DJ, Herman JM, Kain TS, Siwak-Tapp C, Casey C, He J, Ali SM, Klempner SJ, Miller VA (2014) Next-generation sequencing reveals a novel NSCLC ALK F1174V mutation and confirms ALK G1202R mutation confers high-level resistance to alectinib (CH5424802/RO5424802) in ALK-rearranged NSCLC patients who progressed on crizotinib. J Thorac Oncol 9: 549-553.

Janne PA, Yang JC, Kim DW, Planchard D, Ohe Y, Ramalingam SS, Ahn MJ, Kim SW, Su WC, Horn L, Haggstrom D, Felip E, Kim JH, Frewer P, Cantarini M, Brown KH, Dickinson PA, Ghiorghiu S, Ranson M (2015) AZD9291 in EGFR inhibitor-resistant non-small-cell lung cancer. N Engl J Med 372: 1689-1699.
Johnson ML, Yu HA, Hart EM, Weitner BB, Rademaker AW, Patel JD, Kris MG, Riely GJ (2015) Phase I/II study of HSP90 inhibitor AUY922 and erlotinib for EGFR-mutant lung cancer with acquired resistance to epidermal growth factor receptor tyrosine kinase inhibitors. J Clin Oncol 33: 1666-1673.

Katayama R, Lovly CM, Shaw AT (2015) Therapeutic targeting of anaplastic lymphoma kinase in lung cancer: a paradigm for precision cancer medicine. Clin Cancer Res 21: 2227-2235.

Katayama R, Friboulet L, Koike S, Lockerman EL, Khan TM, Gainor JF, Iafrate AJ, Takeuchi K, Taiji M, Okuno Y, Fujita N, Engelman JA, Shaw AT (2014) Two novel ALK mutations mediate acquired resistance to the next-generation ALK inhibitor alectinib. Clin Cancer Res 20: 5686-5696.

Katayama R, Shaw AT, Khan TM, Mino-Kenudson M, Solomon BJ, Halmos B, Jessop NA, Wain JC, Yeo AT, Benes C, Drew L, Saeh JC, Crosby K, Sequist LV, Iafrate AJ, Engelman JA (2012) Mechanisms of acquired crizotinib resistance in ALK-rearranged lung cancers. Sci Transl Med 4: 120ra117.

Kawakami H, Okamoto I, Okamoto W, Tanizaki J, Nakagawa K, Nishio K (2014) Targeting MET amplification as a new oncogenic driver. Cancers (Basel) 6: 1540-1552.

Kim HR, Kim WS, Choi YJ, Choi CM, Rho JK, Lee JC (2013) Epithelialmesenchymal transition leads to crizotinib resistance in H2228 lung cancer cells with EML4-ALK translocation. Mol Oncol 7: 1093-1102.

Kwak EL, Bang YJ, Camidge DR, Shaw AT, Solomon B, Maki RG, Ou SH, Dezube BJ, Janne PA, Costa DB, Varella-Garcia M, Kim WH, Lynch TJ, Fidias P, Stubbs H, Engelman JA, Sequist LV, Tan W, Gandhi L, Mino-Kenudson M, Wei GC, Shreeve SM, Ratain MJ, Settleman J, Christensen JG, Haber DA, Wilner K, Salgia R, Shapiro GI, Clark JW, Iafrate AJ (2010) Anaplastic lymphoma kinase inhibition in non-small-cell lung cancer. N Engl J Med 363: 1693-1703.

Lovly CM, Shaw AT (2014) Molecular pathways: resistance to kinase inhibitors and implications for therapeutic strategies. Clin Cancer Res 20: 2249-2256.

Neckers L, Workman P (2012) Hsp90 molecular chaperone inhibitors: are we there yet? Clin Cancer Res 18: 64-76.

Normant E, Paez G, West KA, Lim AR, Slocum KL, Tunkey C, McDougall J, Wylie AA, Robison K, Caliri K, Palombella VJ, Fritz CC (2011) The Hsp90 inhibitor IPI-504 rapidly lowers EML4-ALK levels and induces tumor regression in ALK-driven NSCLC models. Oncogene 30: 2581-2586.

Ou SH, Greenbowe J, Khan ZU, Azada MC, Ross JS, Stevens PJ, Ali SM, Miller VA, Gitlitz B (2015) I1171 missense mutation (particularly I1171N) is a common resistance mutation in ALK-positive NSCLC patients who have progressive disease while on alectinib and is sensitive to ceritinib. Lung Cancer 88: 231-234.

Paez JG, Janne PA, Lee JC, Tracy S, Greulich H, Gabriel S, Herman P, Kaye FJ, Lindeman N, Boggon TJ, Naoki K, Sasaki H, Fujii Y, Eck MJ, Sellers WR, Johnson BE, Meyerson M (2004) EGFR mutations in lung cancer: correlation with clinical response to gefitinib therapy. Science 304: $1497-1500$.

Pao W, Miller VA, Politi KA, Riely GJ, Somwar R, Zakowski MF, Kris MG, Varmus H (2005) Acquired resistance of lung adenocarcinomas to gefitinib or erlotinib is associated with a second mutation in the EGFR kinase domain. PLoS Med 2: e73.

Paraiso KH, Haarberg HE, Wood E, Rebecca VW, Chen YA, Xiang Y, Ribas A, Lo RS, Weber JS, Sondak VK, John JK, Sarnaik AA, Koomen JM, Smalley KS (2012) The HSP90 inhibitor XL888 overcomes BRAF inhibitor resistance mediated through diverse mechanisms. Clin Cancer Res 18: 2502-2514.

Pearl LH, Prodromou C, Workman P (2008) The Hsp90 molecular chaperone: an open and shut case for treatment. Biochem J 410: 439-453.

Rohner N, Jarosz DF, Kowalko JE, Yoshizawa M, Jeffery WR, Borowsky RL, Lindquist S, Tabin CJ (2013) Cryptic variation in morphological evolution: HSP90 as a capacitor for loss of eyes in cavefish. Science 342: 1372-1375.

Sang J, Acquaviva J, Friedland JC, Smith DL, Sequeira M, Zhang C, Jiang Q, Xue L, Lovly CM, Jimenez JP, Shaw AT, Doebele RC, He S, Bates RC, Camidge DR, Morris SW, El-Hariry I, Proia DA (2013) Targeted inhibition of the molecular chaperone Hsp90 overcomes ALK inhibitor resistance in non-small cell lung cancer. Cancer Discov 3: 430-443.

Sequist LV, Gettinger S, Senzer NN, Martins RG, Janne PA, Lilenbaum R, Gray JE, Iafrate AJ, Katayama R, Hafeez N, Sweeney J, Walker JR, Fritz C, Ross RW, Grayzel D, Engelman JA, Borger DR, Paez G, Natale R (2010) Activity of IPI-504, a novel heat-shock protein 90 inhibitor, in patients 
with molecularly defined non-small-cell lung cancer. J Clin Oncol 28: 4953-4960.

Seto T, Kiura K, Nishio M, Nakagawa K, Maemondo M, Inoue A, Hida T, Yamamoto N, Yoshioka H, Harada M, Ohe Y, Nogami N, Takeuchi K, Shimada T, Tanaka T, Tamura T (2013) CH5424802 (RO5424802) for patients with ALK-rearranged advanced non-small-cell lung cancer (AF-001JP study): a single-arm, open-label, phase 1-2 study. Lancet Oncol 14: $590-598$.

Shaw AT, Kim DW, Mehra R, Tan DS, Felip E, Chow LQ, Camidge DR, Vansteenkiste J, Sharma S, De Pas T, Riely GJ, Solomon BJ, Wolf J, Thomas M, Schuler M, Liu G, Santoro A, Lau YY, Goldwasser M, Boral AL, Engelman JA (2014) Ceritinib in ALK-rearranged non-smallcell lung cancer. N Engl J Med 370: 1189-1197.

Shimamura T, Li D, Ji H, Haringsma HJ, Liniker E, Borgman CL, Lowell AM, Minami Y, McNamara K, Perera SA, Zaghlul S, Thomas RK, Greulich H, Kobayashi S, Chirieac LR, Padera RF, Kubo S, Takahashi M, Tenen DG, Meyerson M, Wong KK, Shapiro GI (2008) Hsp90 inhibition suppresses mutant EGFR-T790M signaling and overcomes kinase inhibitor resistance. Cancer Res 68: 5827-5838.

Shimamura T, Lowell AM, Engelman JA, Shapiro GI (2005) Epidermal growth factor receptors harboring kinase domain mutations associate with the heat shock protein 90 chaperone and are destabilized following exposure to geldanamycins. Cancer Res 65: 6401-6408.

Shimamura T, Perera SA, Foley KP, Sang J, Rodig SJ, Inoue T, Chen L, Li D, Carretero J, Li YC, Sinha P, Carey CD, Borgman CL, Jimenez JP, Meyerson M, Ying W, Barsoum J, Wong KK, Shapiro GI (2012) Ganetespib (STA-9090), a nongeldanamycin HSP90 inhibitor, has potent antitumor activity in in vitro and in vivo models of non-small cell lung cancer. Clin Cancer Res 18: 4973-4985.

Smyth T, Paraiso KH, Hearn K, Rodriguez-Lopez AM, Munck JM, Haarberg HE, Sondak VK, Thompson NT, Azab M, Lyons JF, Smalley KS, Wallis NG (2014) Inhibition of HSP90 by AT13387 delays the emergence of resistance to BRAF inhibitors and overcomes resistance to dual BRAF and MEK inhibition in melanoma models. Mol Cancer Ther 13: 2793-2804.

Smyth T, Van Looy T, Curry JE, Rodriguez-Lopez AM, Wozniak A, Zhu M, Donsky R, Morgan JG, Mayeda M, Fletcher JA, Schoffski P, Lyons J, Thompson NT, Wallis NG (2012) The HSP90 inhibitor, AT13387, is effective against imatinib-sensitive and -resistant gastrointestinal stromal tumor models. Mol Cancer Ther 11: 1799-1808.

Socinski MA, Goldman J, El-Hariry I, Koczywas M, Vukovic V, Horn L, Paschold E, Salgia R, West H, Sequist LV, Bonomi P, Brahmer J, Chen LC, Sandler A, Belani CP, Webb T, Harper H, Huberman M, Ramalingam S, Wong KK, Teofilovici F, Guo W, Shapiro GI (2013) A multicenter phase II study of ganetespib monotherapy in patients with genotypically defined advanced non-small cell lung cancer. Clin Cancer Res 19: 3068-3077.

Soda M, Choi YL, Enomoto M, Takada S, Yamashita Y, Ishikawa S, Fujiwara S, Watanabe H, Kurashina K, Hatanaka H, Bando M, Ohno S, Ishikawa Y, Aburatani H, Niki T, Sohara Y, Sugiyama Y, Mano H (2007) Identification of the transforming EML4-ALK fusion gene in non-small-cell lung cancer. Nature 448: 561-566.
Tanizaki J, Okamoto I, Okabe T, Sakai K, Tanaka K, Hayashi H, Kaneda H, Takezawa K, Kuwata K, Yamaguchi H, Hatashita E, Nishio K, Nakagawa K (2012) Activation of HER family signaling as a mechanism of acquired resistance to ALK inhibitors in EML4-ALK-positive non-small cell lung cancer. Clin Cancer Res 18: 6219-6226.

Thress KS, Paweletz CP, Felip E, Cho BC, Stetson D, Dougherty B, Lai Z, Markovets A, Vivancos A, Kuang Y, Ercan D, Matthews SE, Cantarini M, Barrett JC, Janne PA, Oxnard GR (2015) Acquired EGFR C797S mutation mediates resistance to AZD9291 in non-small cell lung cancer harboring EGFR T790M. Nat Med 21: 560-562.

Whitesell L, Santagata S, Mendillo ML, Lin NU, Proia DA, Lindquist S (2014) HSP90 empowers evolution of resistance to hormonal therapy in human breast cancer models. Proc Natl Acad Sci USA 111: 18297-18302.

Wilson FH, Johannessen CM, Piccioni F, Tamayo P, Kim JW, Van Allen EM, Corsello SM, Capelletti M, Calles A, Butaney M, Sharifnia T, Gabriel SB, Mesirov JP, Hahn WC, Engelman JA, Meyerson M, Root DE, Janne PA, Garraway LA (2015) A functional landscape of resistance to ALK inhibition in lung cancer. Cancer Cell 27: 397-408.

Woodhead AJ, Angove H, Carr MG, Chessari G, Congreve M, Coyle JE, Cosme J, Graham B, Day PJ, Downham R, Fazal L, Feltell R, Figueroa E, Frederickson M, Lewis J, McMenamin R, Murray CW, O’Brien MA, Parra L, Patel S, Phillips T, Rees DC, Rich S, Smith DM, Trewartha G, Vinkovic M, Williams B, Woolford AJ (2010) Discovery of (2,4-dihydroxy-5isopropylphenyl)-[5-(4-methylpiperazin-1-ylmethyl)-1,3-dihydrois oindol-2yl]methanone (AT13387), a novel inhibitor of the molecular chaperone Hsp90 by fragment based drug design. J Med Chem 53: 5956-5969.

Workman P, Aboagye EO, Balkwill F, Balmain A, Bruder G, Chaplin DJ, Double JA, Everitt J, Farningham DA, Glennie MJ, Kelland LR, Robinson V, Stratford IJ, Tozer GM, Watson S, Wedge SR, Eccles SA. Committee of the National Cancer Research Institute (2010) Guidelines for the welfare and use of animals in cancer research. Br J Cancer 102: 1555-1577.

Yamaguchi N, Lucena-Araujo AR, Nakayama S, de Figueiredo-Pontes LL, Gonzalez DA, Yasuda H, Kobayashi S, Costa DB (2014) Dual ALK and EGFR inhibition targets a mechanism of acquired resistance to the tyrosine kinase inhibitor crizotinib in ALK rearranged lung cancer. Lung Cancer 83: 37-43.

Yang JC, Shih JY, Su WC, Hsia TC, Tsai CM, Ou SH, Yu CJ, Chang GC, Ho CL, Sequist LV, Dudek AZ, Shahidi M, Cong XJ, Lorence RM, Yang PC, Miller VA (2012) Afatinib for patients with lung adenocarcinoma and epidermal growth factor receptor mutations (LUX-Lung 2): a phase 2 trial. Lancet Oncol 13: 539-548.

Yu HA, Riely GJ, Lovly CM (2014) Therapeutic strategies utilized in the setting of acquired resistance to EGFR tyrosine kinase inhibitors. Clin Cancer Res 20: 5898-5907.

This work is published under the standard license to publish agreement. After 12 months the work will become freely available and the license terms will switch to a Creative Commons AttributionNonCommercial-Share Alike 4.0 Unported License.

Supplementary Information accompanies this paper on British Journal of Cancer website (http://www.nature.com/bjc) 